\title{
MULTI-CRITERIA ASSESSMENT OF VISEGRAD GROUP ECONOMIES' PERFORMANCE
}

\author{
Jana Masárová ${ }^{124}$ \\ Eva Ivanová125
}

https://doi.org/10.31410/itema.2018.294

\begin{abstract}
To assess the economic performance of states, there are indicators reflecting their economic success. In developed countries of world economy, in addition to economic development, also the social, environmental and other factors, which particularly affect the quality of life or the welfare of the country's population, are becoming more and more significant. Within the criticism of gross domestic product, several alternative approaches and indexes have emerged, such as Human Development Index, Global Competitiveness Index, Legatum Prosperity Index, Index of Economic Freedom and others. The aim of this article is to find the dependence between the gross domestic product per capita and the selected alternative indicators, and to evaluate the performance of Visegrad Group countries.
\end{abstract}

Keywords: Performance, Gross domestic product, Human Development Index, Global Competitiveness Index, Legatum Prosperity Index, Index of Economic Freedom, Visegrad Group

\section{INTRODUCTION, GOAL AND METHODS}

7 he current society pays a great attention to the assessment of economic performance and social development not only regarding scientific research, but also in terms of formulating the starting points for practical economic policy. Thus, the economy performance assessment is very important not only because of theory but also economic policy and practice. Based on studying the achieved level of macroeconomic variables and their development it is possible to understand and explain many problems related to economic growth, the cyclical development of an economy, the relationship between consumption, savings and investment, inflation and unemployment issues, macroeconomic balance and quality of life.

Indicators evaluating economic performance of states are reflecting their economic success however in advanced countries of the world, in addition to economic development, the social, environmental and other factors, generally affecting the quality of life, the welfare of country's population, are to be used more and more. Regarding the criticism of unilateral focus on economic indicators assessing the performance of particular economies, new indicators have emerged that represent an alternative option to basic economic indicator, such as GDP.

The goal of the paper is to present the results of our own research in the field of economic performance theory, its measurement, analysis and use of alternative indicators containing the

\footnotetext{
${ }^{124}$ Alexander Dubček University of Trenčín, Faculty of Social and Economic Relations, Trenčín, Študentská 3, Slovak Republic

${ }^{125}$ Alexander Dubček University of Trenčín, Faculty of Social and Economic Relations, Trenčín, Študentská 3, Slovak Republic
} 
social aspect of economic development of a society. In the study, we evaluate the dependence of selected alternative indicators of economic performance (Human Development Index, Global Competitiveness Index, Prosperity Index, Index of Economic Freedom) and GDP per capita in Visegrad Group countries (Slovak Republic - SR, Czech Republic - CR, Hungary - HU and Poland - PL), and based on a multi-criteria approach, we evaluate the economic performance of Visegrad Group countries. We use statistical data from Eurostat [1] and other relevant institutions reporting those alternative indicators [2] - [5].

In this study the methods of analysis, comparison and synthesis are to be used. We also use the Pearson's correlation coefficient to calculate the dependency of selected alternative indicators and GDP per capita, and the scoring method to assess the performance of Visegrad countries.

The Pearson's correlation coefficient $r$ measures the linear correlation between two variables $\mathrm{X}$ and $\mathrm{Y}$ and can be defined as:

$$
r=\frac{\sum(X-\bar{X})(Y-\bar{Y})}{\sqrt{\sum(X-\bar{X})^{2} \sum(Y-\bar{Y})^{2}}}
$$

where:

$\mathrm{X}, \mathrm{Y}=$ the individual variable

$=$ the sample mean of variable $\mathrm{X}, \mathrm{Y}$

It has a value between +1 and -1 , where 1 is total positive linear correlation, 0 is no linear correlation, and -1 is total negative linear correlation.

To evaluate the economy performance of Visegrad Group countries, we use one of the multicriteria methods - the scoring method. In scoring method, within the each indicator we assign 100 point to the country reaching the highest score, and we assign the following points to the other states as follows:

To the other states as follows:

$$
b_{i j}=x_{i j} / x_{j \max } \times 100
$$

Where:

$x i j=$ the value of the $j$-indicator in the $i$-state

$x j \max =$ the highest value of the $j$ - indicator

$\mathrm{bij}=$ point assessment of $\mathrm{i}$ - state for $\mathrm{j}$ - indicator.

Then we calculate the integral indicator di as the sum of points from particular indicators for each country. The best is the state where the integral indicator will reach the highest value.

The scoring method shows, through the number of points being obtained, the relative differences among states in observed indicators, while all territorial units are being compared with the best territorial unit in particular indicator. The advantage is the ability to aggregate the indicators being evaluated by different measure units into one synthetic characteristic, which represents a dimensionless number. By means of the integral indicator obtained this way, it is 
possible to determine the ranking of individual states, as well as to identify differences among countries and determine how countries are lagging behind each other.

In professional literature and scientific papers, the scoring method is used due to various reasons; however there are different types (forms) of it. Scoring method as one of the methods for multi-criteria evaluation of variants and performance of enterprises is presented by Neumannová [6], Synek et al. [7], Zalai et al. [8], Rejnuš [9] and others. The scoring method, as a method - how to assess the level of regions based on a number of indicators and subsequently to assess regional differences, is presented, for example, by Kutscherauer et al. [10], Tuleja [11], Svatošová and Novotná [12], Michálek [13], Hamada [14]. To assess the performance of states by a scoring method provides a comprehensive view how the observed countries are successful. However, the results of such assessment depend on the indicators being chosen and on the countries being involved in the survey.

\section{THEORETICAL BASIS FOR THE ECONOMIC PERFORMANCE OF STATES ASSESSMENT}

The goal of advanced economies in the world is to increase their economic performance, which is an expression of their economic success. The issue of economic performance is observed by many authors, such as Nordhaus and Tobin [15], Piketty and Saez [16], Osberg and Sharpe [17], Lisý [18], Habánik [19], Klvačová and Malý [20], Havierniková and Koišová [21] and others. By all mentioned authors the gross domestic product is considered to be the basic indicator for the assessment of state economic performance. The Gross Domestic Product (GDP) is considered to be a basic economic indicator because it reflects the performance of an economy based on the result of production factors activity being located in the territory of a country. In monetary terms, it is presented by the value of final products and services produced in the territory of a particular country in a certain period (e.g. year), no matter who is the owner of the production factors being created, it is about the final products and services that went through the official market.

Either way, this indicator measures only the economic performance of a country over a certain period. The imperfections being showed by GDP can be divided into three basic groups according to the sources of inaccuracies and imperfections that GDP includes. In particular, there are inaccuracies caused by distorted valuation, inaccuracies caused by incompleteness of data and inaccuracies resulting from the principal structure of GDP.

According to Večerník [22], against the gross domestic product being as a leading indicator a research on its critique and construction alternative indicators have been raising for several decades to better reflect and express the overall performance of economy as well as social system.

We agree with Krajňáková and Vojtovič [23] that by the GDP as indicator which main task is to assess the final production, it cannot be expected to measure and evaluate all other aspects of people's lives. That is why for a more accurate and detailed assessment of economy's performance and well-being, it is appropriate to use a combination of several indicators that take into account other aspects reflecting how the society is being developed.

In response to the unilateral usage criticism of gross domestic product as an indicator to measure the economy performance, in the second half of the twentieth century new indicators are emerging as an alternative way to this basic macroeconomic indicator taking into account also 
other aspects of life for the population in society. The performance of national economies is then assessed on the basis of different areas how the society is running and the quality of life of its population. For example, it can be an assessment on rating the human development, prosperity, competitiveness, social welfare, or economic freedom.

Human Development Index (HDI) is an indicator designed by United Nations to assess the status and development of human development rate and apart from the economic aspects (gross national income per capita) it is taking into account other the economic aspects of human development such as life expectancy and level of education.

The competitiveness of economy is assessed by the World Economic Forum by means of the Global Competitiveness Index (GCI). This index examines the ability of an economy to compete in international economy, taking into account 12 areas of competitiveness.

The term prosperity appears to be an alternative concept for performance. Prosperity as a multidimensional magnitude is assessed by Legatum Institute, based in London, by means of Legatum Prosperity Index (LPI). Prosperity is evaluated on the basis of nine areas (pillars).

More often, in the literature, the performance and economic level of states is linked to economic freedom. Economic freedom as a complex of individual partial freedoms is able to be quantified by measuring these partial components. The US Heritage Foundation, in collaboration with The Wall Street Journal, is compiling an Index of Economic Freedom (IEF) as a study annually assessing the level of economic freedom based on 12 components of freedom.

Each of these alternative ways to assess the performance of economies has (as well as GDP) its strengths and weaknesses. The shortcomings of these indexes result, for example, from the reliability, respectively inaccuracy of particular sub-indicators, the interchangeability of indicators, and the usage of so-called "soft data" and so on.

\section{THE DEPENDENCE OF ANALYZED ALTERNATIVE INDICATORS AND GDP IN V4 COUNTRIES}

Based on the analysis of GDP per capita, HDI, LPI, GCI and IEF, we examine the dependency of assessed indicators and gross domestic product per capita by means of Pearson correlation coefficient. This dependence was evaluated for the 2007-2016-time series, regarding the variable of Human Development Index it is the period of 2007-2015, as data for 2016 has not yet been published. The correlation coefficient values are shown in Figure 1. 
Figure 1: The dependence of GDP and selected alternative indicators (correlation coefficient)

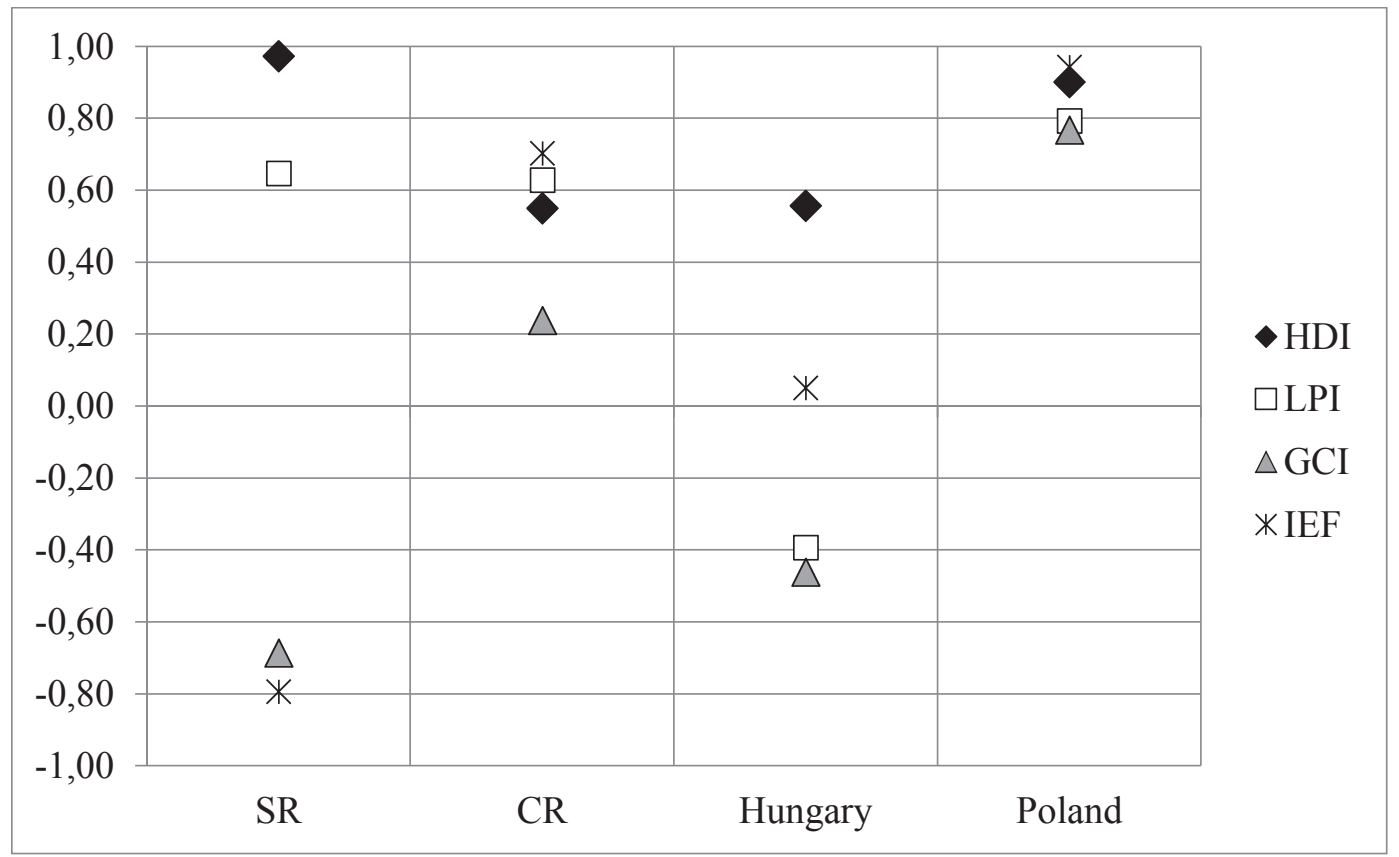

Source: own processing, own calculations

The results of correlation analysis show the different values for the dependence of GDP and indicators assessed in individual Visegrad Group countries. The strong GDP and HDI dependence has been proved in Slovak Republic and Poland. In Czech Republic and Hungary, we can see a moderate GDP and HDI dependence.

GDP and LPI dependence is moderate in all countries, apart from Hungary where dependence is indirect. In case of GCI, the results in individual countries are very different, ranging from the negative dependence in SR and Hungary to the moderately strong dependence in Poland.

When assessing the GDP and IEF dependency we can see the negative dependence in Slovak Republic, meaning that GDP per capita is increasing despite the economic freedom is getting worse. In Poland, the GDP and IEF dependence is strong.

\section{MULTI-CRITERIA EVALUATION OF VISEGRAD GROUP COUNTRIES PERFORMANCE}

Regarding the V4 countries multi-criteria evaluation, we take into account the results of individual states in the basic macroeconomic indicator and in the selected alternative indicators, i.e. we evaluate the following variables: GDP per capita, HDI, GCI, LPI and IEF. The assessment is executed during the period for which the data is available in all selected indicators i.e. for the years of 2007-2015.

\subsection{THE V4 COUNTRIES PERFORMANCE IN 2007}

Year 2007 is the first year when the economy performance alternative indicators values of all the V4 countries are available for the assessment process. Based on the results achieved within the GDP per capita indicator and selected alternative indicators, by scoring method we assessed the performance of individual V4 countries' economies. The comparison of integral indicators 
in V4 countries within the structure according to the number of points being obtained for each indicator is shown in Figure 2.

In 2007, the best rating, a total of 496.84 points, was obtained by Czech Republic, achieving the best results in four out of the five observed indicators, only slightly behind SR within the IEF indicator. SR obtained 29.61 points and ranked the second position (it received a total of 467.23 points), when reaching a fairly balanced rating in each indicator, apart from the GDP per capita indicator. Hungary got the third position with a sum of 452.98 points, having the weakest rating in GDP per capita. Poland finished with a score of 427.76 points.

The most balanced points were obtained by the countries in LPI and GCI indicators, while the largest gap between the best performing country CR and other V4 countries was in GDP per capita, where Poland reached only $61.2 \%$ of GDP per capita in CR.

Figure 2: V4 countries performance in 2007. Source: own processing, own calculations

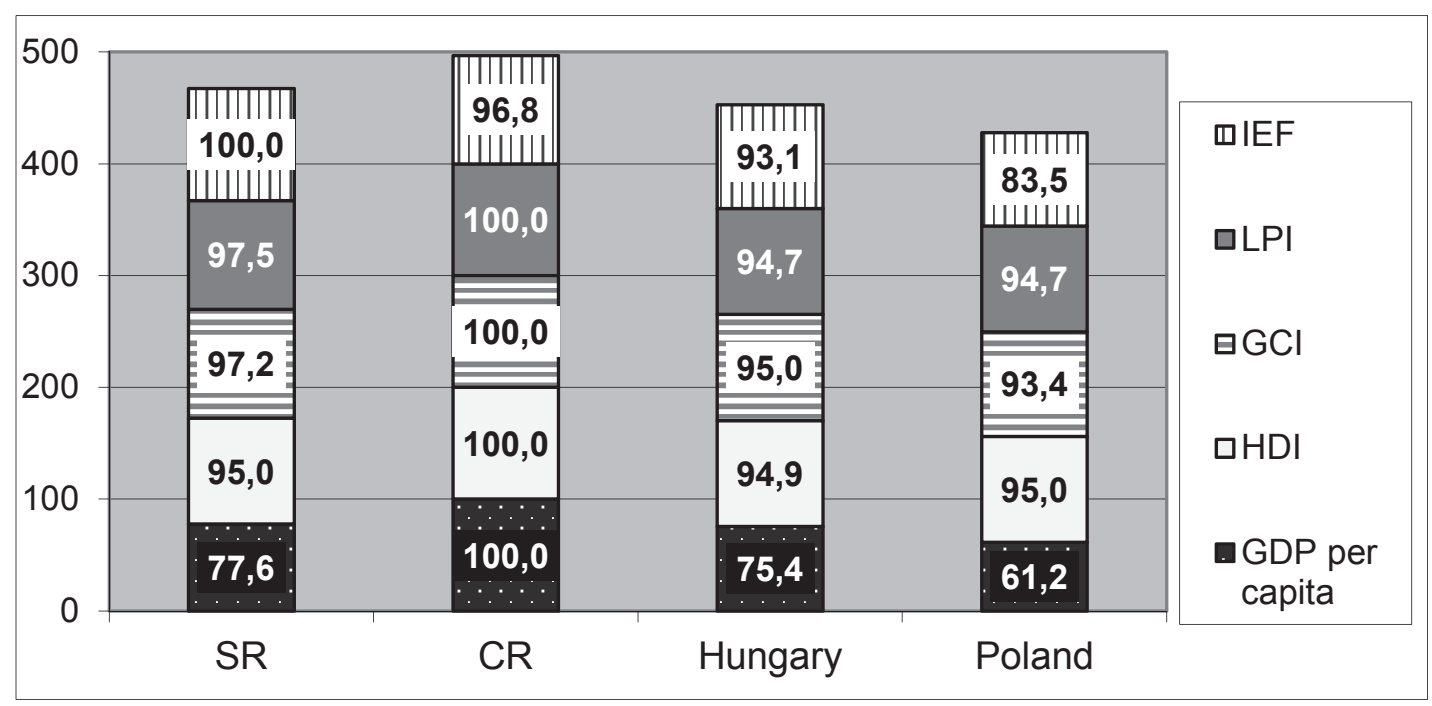

\subsection{THE V4 COUNTRIES PERFORMANCE IN 2015}

Year 2015 is the last year in which the data is available for all observed indicators. The performance of V4 states in 2015 as determined by the scoring method is shown in Figure 3.

Figure 3: V4 countries performance in 2015. Source: own processing, own calculations

\begin{tabular}{|c|c|c|c|c|c|}
\hline \multirow{3}{*}{$\begin{array}{l}500 \\
400\end{array}$} & \multirow{3}{*}{ 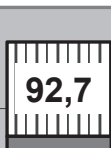 } & $\|$ & \multirow{3}{*}{ 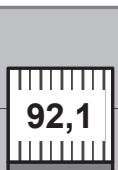 } & \multirow{3}{*}{\begin{tabular}{|l|l|}
$T ा T ा T ा T$ \\
94,6 \\
ШШШШ
\end{tabular}} & \multirow[b]{2}{*}{ هIEF } \\
\hline & & 100,0 & & & \\
\hline & & & & & \\
\hline \multirow{2}{*}{300} & 95,2 & & 015 & 96,5 & $5 \mathrm{rI}$ \\
\hline & 90,0 & 100,0 & & 057 & $\mathrm{EGCl}$ \\
\hline 200 & 96,2 & 100,0 & $05 ?$ & 071 & 口HDI \\
\hline 100 & 91.8 & 100.0 & & & - GDP per \\
\hline \multirow[t]{2}{*}{0} & & & & & capita \\
\hline & SR & CR & Hungar & Polanc & \\
\hline
\end{tabular}


Also in 2015, CR had the best results in all evaluated indicators, reaching the maximum value of integral indicator (500 p.). The second notch belongs to SR (465.91 p.), worsening its position in comparison with 2012 in all indicators except GDP per capita.

Third in ranking, Poland has achieved better results than in 2007 (455.13 p.), but being behind SR by $10.78 \mathrm{p}$. The last is Hungary, where the value of integral indicator has been reduced to 439.76 points as compared to 2012 due to worse assessment in all indicators, apart from GDP per capita.

\subsection{THE V4 COUNTRIES PERFORMANCE COMPARISON IN 2007-2015}

The results of V4 countries were also quantified by using the scoring method for the other years of the 2007-2015-time series and the development of integral indicator values during the selected time series is shown in Figure 4.

Figure 4: V4 countries performance comparison in 2007-2015. Source: own processing, own calculations

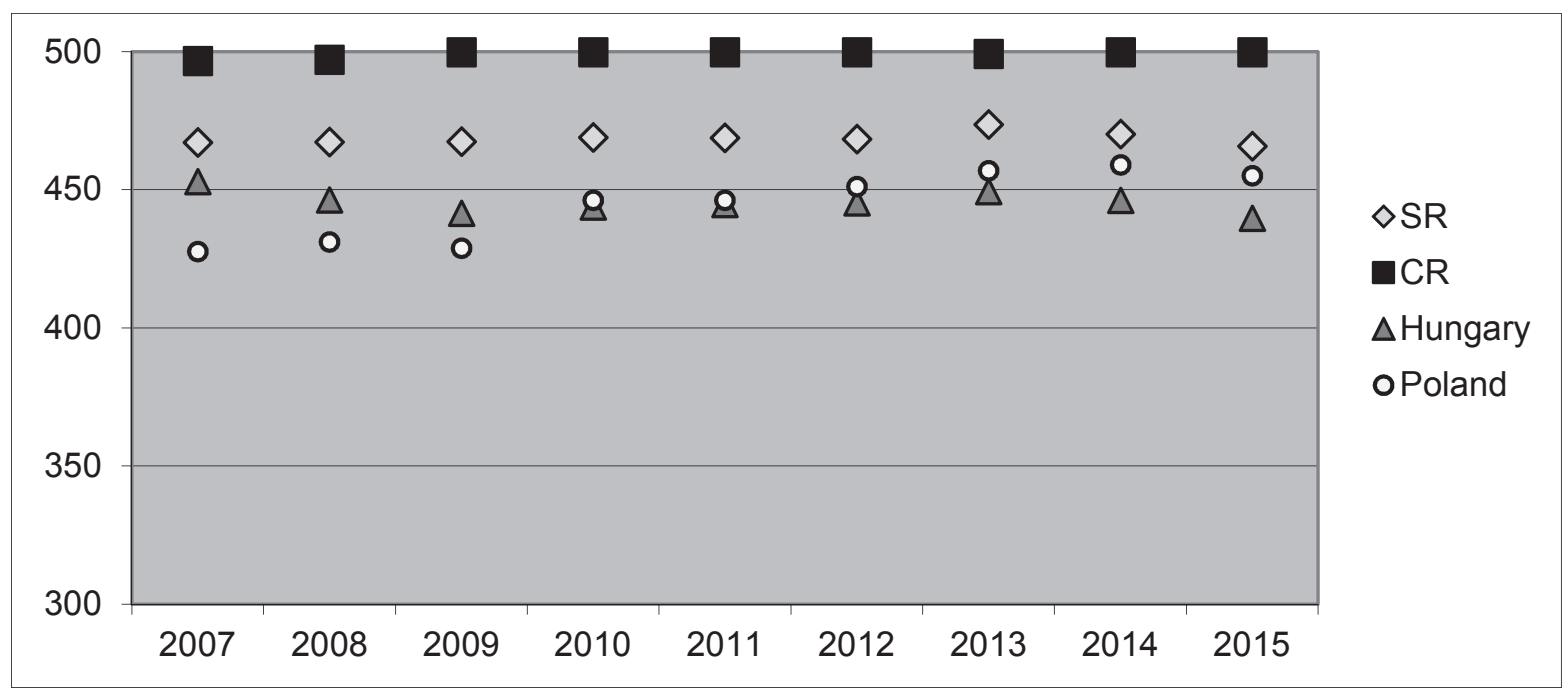

From the previous analyzes as well as from the graphical presentation, it follows that in the period of 2007-2015 CR has achieved the best results within the V4 countries in the observed indicators. In the six out of nine observed years, Czech Republic has received the best rating in all selected indicators.

The performance of SR has been increasing almost every year (apart from the last two years) i.e. approaching the CR level. The best rating has been reached by SR in $2013-473.31$ points. Poland's performance rating has been increasing, but in 2009 and 2015 there was a slight decline in its performance. Poland scored the most points in $2014-459.09$ points.

In the first three years Hungary has been more successful than Poland, but has reached the lowest amount of points since 2010 within the V4 countries. In 2007 Hungary reached 452.98 points, in 2015 only 439.76 points.

Generally speaking, the difference within the performance of V4 states are decreasing, i.e. the gap between the other V4 countries and CR (except Hungary) has become smaller during the 
observed period. The smallest differences within the of V4 countries performance detected by the scoring method were in 2013 and 2014.

The largest differences can be seen in GDP per capita indicator; although in the last few years they have been slightly decreasing. The differences within V4 countries performance in the selected alternative indicators are much lower, which also results from the fact that the composite indicators are taking into account mostly the multiple sub-areas of society, companies and individuals, and are aggregating and averaging these sub-variables.

\section{CONCLUSION}

GDP has been and still remains the basic criterion how to assess the economy performance for decades, even though it does not reflect the overall complexity of the country's social and economic development and does not address the issue of the country's economic development in more complexes.

Along with the GDP criticism, several alternative approaches and indexes have emerged to eliminate the imperfections implied by GDP. These alternative concepts and approaches, on one hand, seek to capture the economy performance more precisely, but also are still oriented to extend this concept to other dimensions. In our paper, we focused on selected composite indicators: HDI, GCI, LPI, IEF.

Based on the correlation analysis, we found out strong GDP and HDI dependence in SR and Poland, and a strong dependence of GDP and IEF in Poland. By the Multi-Criteria Analysis of V4 countries' performance, we found out that CR has achieved the best performance, followed by SR. From 2010 Poland has reached the third notch and the last is Hungary. The performance of other V4 countries is close to rating of CR.

The assessment of Visegrad Group economies performance through the scoring method is only one of the options for a comprehensive multi-criteria assessment of economic and social levels of states. We realize that the scoring method as a multi-criteria method guarantees a certain degree of objectivism, but it also has certain pitfalls resulting from subjectivism, which is related to the selection of assessed indicators that may not fully reflect economic performance and social progress in a country. Another barrier to more detailed research over a longer timeframe are the different reporting periods for each alternative performance indicator and the unavailability of data for the last completed year. Nevertheless, we believe that the results of our research will be beneficial to other fields of economic science, especially macroeconomics, and will become the basis for further research on the issue.

\section{REFERENCES}

[1] Eurostat. (2017) Database, Available at: http://ec.europa.eu/eurostat/data/database.

[2] UNDP. (2017) Human Development Report 2016, Available at: http://hdr.undp.org/sites/default/files/2016_human_development_report.pdf

[3] Legatum Institute. (2017) The Legatum Prosperity Index, London: Legatum Institute. Available at: http://www.prosperity.com.

[4] The Heritage Foundation. (2017) Index of Economic Freedom, Available at: http://www.heritage.org/index/. 
[5] WEF. (2017) The Global Competitiveness Report 2017-2018, Available at: http://www3.weforum.org/docs/GCR2017-2018/05FullReport/

TheGlobalCompetitivenessReport2017\%E2\%80\%932018.pdf

[6] Neumannová, A. (2007) Podniková diagnostika, Bratislava: EKONÓM.

[7] Synek, M., Kopkáně, H., Kubálková, M. (2009) Manažerské výpočty a ekonomická analýza, Praha: C.H. Beck.

[8] Zalai, K. et al. (2010) Finančno-ekonomická analýza podniku, Bratislava: Sprint dva.

[9] Rejnuš, O. (2014) Finanční trhy, Praha: Grada Publishing.

[10] Kutscherauer, A., Fachinelli, H., Hučka, M., Skokan, K., Sucháček, J., Tománek, P., Tuleja, P. (2010) Regionální disparity. Disparity v regionálním rozvoji země - pojetí, teorie, identifikace a hodnocení, Ostrava: VŠB-TU Ostrava.

[11] Tuleja, P. (2010) Praktická aplikace metod hodnocení regionálních disparit. In: Acta academica karviniensis, No. 1 (2010). Karviná: SU OPF.

[12] Svatošová, L. Novotná, Z. (2012) Regionální disparity a jejich vývoj v ČR v letech 19962010. In: Acta Universitatis Bohemiae Meridionales, The Scientific Journal for Economics, Management and Trade, Vol. 15, no. 1, pp. 103-110.

[13] Michálek, A. (2012) Vybrané metódy merania regionálnych disparít. In: Geografický časopis, Vol. 64, no. 3, pp. 219-235.

[14] Hamada, R. (2014) Vybrané spôsoby a metódy merania a hodnotenia regionálnych disparít. In: Regionální rozvoj mezi teorií a praxí, No 1, pp. 21-34.

[15] Nordhaus, W., Tobin, J. (1973) Is Growth Obsolete. In: The Measurement of Economic and Social Performance, ed. Milton Moss, 509-534, New York: Columbia University Press.

[16] Piketty, T. Saez, E. (2001) Income Inequality in the United States, 1913 to 1998. In: National Bureau of Economic Research Working Paper, Available at: http://www.nber.org/papers/w8467.pdf.

[17] Osberg, L., Sharpe, A. (2005) How should we measure the 'economic' aspects of wellbeing? In: Review of Income and Wealth, Vol. 51, issue 2, pp. 311-336. doi:10.1111/j.1475-4991.2005.00156.x.

[18] Lisý, J. (2005) Makroekonómia 1. Výkonnost' ekonomiky a ekonomický rast, Bratislava: EKONÓMIA.

[19] Habánik， J. (2005) Hodnotenie výkonnosti slovenskej ekonomiky. In: Sociálnoekonomická revue, Vol. 3, no. 2, pp. 53-65.

[20] Klvačová, E., Malý, J. (2008) Domnělé a skutečné bariéry konkurenceschopnosti EÚ a ČR, Praha: Vzdělávací středisko na podporu demokracie.

[21] Havierniková, K., Koišová, E. (2017) The relationship between GDP creation and the selected variables of business environment. In: Actual Problems of Economics, Vol. 187, No.1 (2017), pp. 389-397.

[22] Večerník, J. (2012) Subjektivní indikátory blahobytu: př́stupy, měření a data. In: Politická ekonomie, Vol. 60, no. 3, pp. 291-308.

[23] Krajňáková, E., Vojtovič, S. (2012) Sociologická analýza trhového hospodárstva, Žilina: GEORG. 